\title{
Energy Crises in South Africa and New Ways of Fast-Tracking Remedial Actions Through Diversified and Decentralised Generation
}

\author{
Melusi Nhleko \\ Department of Mechanical Engineering \\ University of Kwazulu-Natal, Durban, South Africa.
}

\author{
Freddie L. Inambao* \\ Department of Mechanical Engineering \\ University of Kwazulu-Natal, Durban, South Africa
}

ORCID: 0000-0001-9922-5434

\begin{abstract}
There no doubt that the South African economy is experiencing a massive blow from the current chronic energy crisis. As a consequence, small businesses are closing, municipalities and other industries and institutions are significantly affected in their operations and ability to provide services. Though global markets call for diversified economies with a mix in the provision of goods and services, South Africa is troubled by inadequacy of energy to support such additional trading in addition to the already existing heavy energy dependent trade activities. The South African government must fast-track its efforts to provide credible and reliable electricity supply through diversified generation and decentralized generation strategies. Thus, this paper highlights the critical nature of the current energy situation and the means of curbing the ripple effect of energy shortages on the ground in municipal jurisdictions.
\end{abstract}

Keywords: Energy utility, security of energy supply, energy crises, decentralisation

\section{INTRODUCTION}

The energy crises in South Africa has reached near catastrophic levels with far reaching consequences that have caused many small-to-medium businesses to close shop and a rise in job losses in the labor market. Government needs to engage in robust 'out-of-the-box / business unusual' approaches and partnership in order to decentralize some of the energy generation and distribution burden to institutions operating at ground level and entrust them with providing services to communities and businesses within jurisdiction. The aim of this paper is to highlight the severity of the energy crises that persists and the means that government could embark on to fast-track the implementation of new forms of energy generation using renewable energy sources.

\section{METHODOLOGY}

\section{A. Background}

The Oxford South African School Dictionary [1] defines 'energy' as the ability or power from electricity that makes machines work. According to [2], energy is one of the major building blocks in modern society and is used to create goods and provide services that contribute to economic development and improved standards of living.

[3] states that the large appetite for electricity/ electrical energy by many societies has stimulated the relative ease with which electricity can be generated, distributed, and utilised. The authors question is whether the consumption of electricity should continue to grow unmonitored or unchecked. Whatever the case, it is evident that there is an ever-increasing demand for this form of energy, thus, in order to meet the world's demand, radical expansion of generating capacity must be a principal focus [3].

[2] states that energy can be best described by what it can do, and that energy cannot be seen, cannot be created nor destroyed, but can be used and its effects observed. Further, the authors state that the interdependent world through its modern economic activities has forged a common quest for collective access to adequate and reliable energy resources, as energy supplies are central to economic growth. Many countries are now seeking to be energy self-sufficient and produce their own power to cater for the energy demands stemming from modernisation and industrialisation. The availability of adequate, reliable and sustainable sources of energy supply is of paramount importance for developing countries such as South Africa, as well-planned use of energy resources with minimal or no wastage together with efficient energy converting technologies must be established [2].

[4] states that the demand for electricity is growing for both developed and developing countries due to increasingly fast industrialization. Energy security has become a global challenge that stems from rising energy demand and increase of conventional generation costs [5]. Growing industrialization and motorization of the world has led to a steep rise in demand for petroleum-based fuel, but the limited reserves of these irreplaceable sources has accelerated the appetite for alternative energy sources [6]. This global energy crisis and continuous increase in energy produce from fossil fuel-based sources has stimulated an urgent need to develop technologies or modify existing technologies that can efficiently convert renewable energy sources to usable form, rendering renewable energy viable to supply the current growing and future projected energy demand.

Energy makes the world work as most of the world's machines and economic activities are powered by energy which can be from non-renewable energy sources such as fossil fuels or from 
renewable sources such as wind, solar and biomass [7]. However, the ongoing unchecked consumption of fossil fuel based energy sources such as oil, coal and natural gases has contributed tremendously to global warming, environmental pollution and increased prices of energy production [8].

[9] states that South Africa is a country that has for the past decade been experiencing serious energy supply challenges. Challenges included are inadequate facilitation of energy structures to support economic growth and development, poor assurance for quality of energy provision and infrastructure efficacy, ineffective infrastructure management on existing infrastructure that promotes energy efficacy, poor planning and innovative means for the construction of new infrastructure and energy capacity, and poor energy and infrastructure life cycle management planning. This has inhibited economic activities and increased energy related consequences suffered by the South African community [9].

South Africa is highly dependent on fast depleting fossil fuel based sources and the costs of generating electricity from these sources are continually rising; the increase in energy demand and consumption trends tend to suggest that the South African government must urgently seek for cheaper and more sustainable alternative energy sources [10]. The Financial Mail (2015) [11] publication on South Africa's energy crisis indicates that the South African government has been playing catch-up since the early 2000s in building sufficient energy capacity to meet current and future demand.

[12] states that the South African economy is extremely energy dependent compared to other countries when using international instruments and standards of determining the energy usage index. Energy trends reflect South Africa's resource endowments, historical underpricing of coal and electricity, and low electricity (energy) efficiency.

Despite the above challenges, the irony is that the South African government has continued in its capital investment endeavors of pursuing fossil (coal)-based sources and commenced in the late 2000 s the construction of two giant power stations with the current costs of the unfinished power plants reflecting more than R300 billion; over R145 billion currently spent for Kusile power station a $4800 \mathrm{MW}$ plant and over R161.4 billion for Medupi power station, a 4764MW drycooled coal-fired power plant. Using Eskom's 2016 financial statements, the total construction costs of building the utility's power plants by end of construction period (early 2020s) are estimated to be R208.7 billion and R239.4 billion for Medupi and Kusile power plants respectively [13].

The Financial Mail [11] indicated that, in order for the South African government to build up sufficient energy capacity to satisfy the current and forecast future demands for high performance skills and other energy related resource processes for fossil-fuel based energy security of supply, R420 billion is required to address South Africa's energy infrastructure plan, and the economic growth of the country is negatively impacted by the lack of power capacity to meet economic activity demands. [14] reports that a lack of capacity impacts the economy in two ways: it reduces local economic activities which in turn force a large number of thriving industries to review their operations, energy utilization and costs, which causes loss in investor confidence as investors worry about energy shortages and future energy supplies that negatively impact production and profits, erode investment related benefits towards growth and expansion of economic activities, and subsequently impact the manner in which operations should be and are actually conducted.

According to [15], Eskom's total carrying value of unaudited debt at the end of March 2019 was R440 billion, of which R273 billion is government guaranteed. Eskom's investment spending cuts in recent years has seen the energy utility face a huge backlog in repairs to existing plants while they are all operating at almost full capacity, and that due to the investment spending cuts there has also been a lag in the construction work of the two giant plants (Kusile and Medupi) and modification (rehabilitation or refurbishment) works on existing plants. Worsening the situation according to [15] is that most of Eskom's ageing coal-based plants are due to reach their allowable working and economic life in the 2020s and some in the early 2030s. This has stimulated a lot of discussions in government, regarding what best can be done to reduce debt and remedy the energy utility, including considering some form of privatization. Options for securing an affordable and sustainable energy supply for the country and its citizens has recently been amongst the top of the agenda, including procuring new sources of energy supply.

In an article titled 'Understanding America's Water and Wastewater Challenges' [16] states that although the general public expects effective delivery of services, the public's understanding of the complicated and expensive systems required to deliver those services is minimal and they reflexively oppose new charges and fees so are reluctant or unable to accept a higher price for services rendered. Therefore, the service providers face the challenge of raising mission-critical funding from a skeptical public while maintaining affordability for those services which makes it difficult for government to provide promised energy supply services.

[14] states that the South African economy is suffering from lack of power, and hundreds of billions of rands need to be invested rapidly to address South Africa's lack of capacity to ensure economic stability. This is because South Africa is currently not in a position to lose both investor confidence (investment) and reduction in production activities. Considering this, and the rising costs of acquiring fossil-fuel (coal) and the rising greenhouse gasses associated with this, the question is: why is the South African government not committing the same amount of money to support the exploration and production of more reliable and sustainable renewable energy sources through various initiatives at different government levels?

Eskom's audited 2018 annual report [17] highlights that debt for energy accumulated by municipalities over the previous 10 years is a staggering R13.6 billion. Although Eskom has undertaken far-reaching strategies of conserving energy supply through load-shedding and awareness, these strategies have not had a significant impact on investor confidence and the already dampened economic activities. This means that industries located and operating within municipal jurisdiction are faced 
with reduced production and labour resources as the energy supplies from both municipalities and Eskom are limited.

Two unfortunate facts are: government's support for renewable energy is on a small scale and the South African government unfortunately perceives seeking and securing alternative energy supply as an expensive exercise in the current ailing (weak) economy. The question is: why is it taking government such a long time to formulate strategies that attempt to curb or address such energy crises, especially contributed by municipalities to the energy sector?

Recently, in the third quarter of South Africa's government 2018/2019 financial year (September 2019 to December 2019), the South African media [18] reported that the South African government through President Cyril Ramaphosa approached 'giant' first world countries and other international platforms such as BRICS in an endeavour to boost investor confidence towards South Africa, managed to acquire investment funding to the value of over 40 billion United States dollars (approximately R580 billion).

The state of South Africa's energy supply can largely be attributed to infrastructure failure, poor energy and infrastructure based planning (nationally, provincially and at municipality level), growing incompetence of technical personnel in government institutions, corruption, socioeconomic ills of poverty which results in activities such as cable theft, inadequate government supported initiatives towards alternative 'out of the box' or 'business unusual' strategies, insufficient allocation of budget towards infrastructure retention and energy conservation, inability of the executive (lack of leadership) in identifying looming challenges and formulating necessary energy supply strategies, and South Africa's lack of strategy aimed at auditing available resources and developing a consolidated energy demand approach that will see the country undertake necessary procurement strategies and time-based implementation plans that address infrastructure backlogs (existing infrastructure conditions) and energy deficits at both national and municipal levels.

According to [9], South Africa is experiencing serious infrastructure challenges from inefficient maintenance of existing infrastructure that had been installed in the late $1960 \mathrm{~s}$ and early 1970s, and also suffers from unmonitored and unaudited usage or consumption of energy. The government interventions required according to [9] among others, are:

- strong public sector leadership

- government commitment and ownership of existing infrastructure and energy demand through comprehensive policies, infrastructure maintenance and restoration programs and initiatives, and technological advancement

- government commitment and ownership of energy efficacy and sourcing meaningful and sustainable solutions in the energy sector such as exploration of readily available renewable energy sources for the South African market or society

- commitment to comprehensive planning in the energy sector and corresponding infrastructure requirements at all levels of government

- commitment to financial investment and support for security of energy supply at all government levels

- commitment towards time-based implementation of the exploration of identified sustainable energy sources as per agreed upon and gazetted national, provincial and municipal energy supply plan and strategies;

- appropriate institutional arrangements and skills development, and

- establishment of suitable support strategies, systems, tools and technologies that solidify infrastructure efficiency [9].

The recently developed National Development Plan (NDP) according to [19] seeks, amongst other things, to provide a framework for government institutions to promote economic development through provision of reliable infrastructure and affordable energy. Although the NDP requires the development of an additional 10000 MW electricity capacity to be established by 2019 against a set baseline of $44000 \mathrm{MW}$, the NDP fails to outline in detail how each strategy can be accomplished through clearly defined comprehensive timebased implementation plans.

[20] states that urgent investment intervention actions are needed to combat infrastructure stresses and energy vulnerability. The author further indicates that amongst the many challenges facing the efficient use of energy and infrastructure performances are ageing infrastructure, lack of or inadequate maintenance attention to infrastructure, lack of technological improvement or modifications to infrastructure, lack of adequate installation of devices that monitor infrastructure condition and energy performance levels, lack of installed devices that support energy efficiency, lack of modelling and controlling of infrastructure loading and energy consumption, and etcetera. According to [20] the above factors heavily contribute to heightened energy consumption, increased energy wastage and the near collapse of the national grid.

A well-functioning system reduces transaction costs. In order to achieve energy efficacy, well-functioning infrastructure systems must be well-maintained, and financial investment to alternative energy sources must be explored as this improves competitiveness by reducing transaction and trade costs [21]. The author further states that financing of public infrastructure must be viewed as a fast-tracking factor for change and must remain as one of the key goals for sustainable development. [22] supports [20]'s view and states that the economic sector is more affected by poor infrastructure conditions, thus infrastructure investment is one of the most important factors related to the growth of economic development than any other factor.

According to [23], South Africa is increasingly becoming a high infrastructure and energy failure rate risk country due to the lack of government spending (intervention) on infrastructure and lack of support for renewable-energy based initiatives which results in amplified energy bills due to 
uncontrolled consumption of energy, lack of infrastructure capacity to cater for increased demand, lack of effective implementation of maintenance programs that seek to restore existing infrastructure to acceptable condition and good levels of performance, and the increasing continued support for coalbased generation.

To settle the persisting energy crises of the country, one of the government initiatives is to identify low hanging fruits that reduce energy demand from the national grid. Emanating from this initiative is a strategy of decentralizing generation to municipalities (public sector institutions) by providing municipalities with the autonomy to generate their own required electricity. In this regard, [24] proposes that municipalities must be empowered to use resources that are readily available at their disposal, such as biomass from municipal sewage and other types of renewable energy sources to generate electricity to power treatment plants and supply communities within jurisdiction.

According to [2], since countries seek to be energy selfsufficient, [25] states that to achieve this countries and governments must be encouraged to support and expand their endeavors to harness renewable sources and develop modified technologies aimed at optimizing the harnessing of energy from renewable sources, and that the development of energy converting technologies must make energy efficacy an achievable reality.

Due to the large amount of energy required to power industries together with their respective treatment requirements, an attempt to reduce energy consumption results in increased efficiency and amount of energy available for use, thus promoting a robust economy [26].

The Department of Energy (DoE) of South Africa acknowledges recommendations by the World Economic Forum (WEF) that:

- energy sources must support economic growth and development

- energy sources must support environmental sustainability, and

- energy sources must support energy access and security [27].

[11] states that the newly developed integrated energy plan (IEP) sets out South Africa's plan for energy (electricity) generation and the crucial role that energy plays in the country's economy and also determines the best way to meet current and future energy service needs in the most efficient, affordable and beneficial manner over a 20-year period with one of the main aims being to improve South Africa's energy supply. [28] suggests that the artificially low electricity tariffs in South Africa should be replaced by a system that better reflects the capital costs of power generation and transmission in order to encourage both local and foreign investment and efficiency improvements in power generating capacity.

Drafting and adopting a differentiated electricity price policy would create effective energy guidelines for South Africa [29]. If differentiated electricity price policies are adopted and implemented in a similar manner to those of the Chinese government, this would encourage electricity savings and improve efficiency [30].

[27] provides the following facts regarding South Africa's electricity market: South Africa's nominal capacity is 44175 MW, $92.6 \%$ is produced from coal-fired stations. The authors state that the electricity demand projections indicate that an additional target of $40000 \mathrm{MW}$ capacity is required by 2025 . Further, in their reporting, they indicated that, although South Africa's renewable energy sector is relatively young, the growing renewable energy industry in South Africa produces about 1415.52 MW, of which 43.6\% (631.53 MW) of the country's renewable energy is produced from solar PV energy system.

The 2018 South African Energy Sector [31] report echoed the above figures and stated that the $40000 \mathrm{MW}$ capacity is required to address previously disadvantaged communities and affordable access to electricity. Meeting this requirement has increasingly caused a steep demand for electricity and this has further increased the load on Eskom's power plants, resulting in the over commitment of the power generating plants [31].

The [27] report further provides that an additional procurement of $18.2 \mathrm{GW}$ of renewable energy is required by 2030 , of which solar PV would be expected to contribute about $46 \%(8.4 \mathrm{GW})$, biomass about $2 \%(0.4 \mathrm{GW})$ and the remaining to other forms of renewable energy sources. The report indicates that the above figures are a reflection of additional energy required but does not include or account for renewable energy required to gradually replace electricity produced from coal-fired stations that are becoming more and more unstable as they coming to the end of their service life. This in other words states that operating the giant coal-fired power stations is proving to be expensive as well as keeping them functional. Thus procurement of renewable energy must be pursued by South African government with great interest in the view of climate change and health reasons as well.

According to [27], although government has in place policies that encourage the undertaking of green project(s) and has proposed over R20 billion towards such project(s), time-based implementation plans and new energy production policies at decentralized institutions such as municipalities are lacking and consideration of energy efficiency as a major contributing factor to energy usage in municipalities and/or any other institutions on the ground authorized to generate and distribute energy receive inadequate drafting of proposed comprehensive strategies and solutions that attempt to address energy inefficiencies.

[27] further points out that government has in place policies that promote green projects based on rebates for installation of energy efficiency and demand management interventions, tax credits for deployment of energy efficiency interventions and investment in green (renewable) projects. These policies include the following:

- Renewable Energy White Paper, 2003

- Energy Efficiency Strategy, 2005

- Regulations on Energy Savings Allowance, 2011

- Integrated Resource Plan (2010-2030), and 


\section{- New Generation Capacity Regulations, 2009}

Unfortunately, the above policies reflect government support for energy generation by private sector institutions and subsidies that benefit the same but lack government commitment of being an active partner in energy generation using renewable energy source(s). This lack of partnership or lack of desire to own diversified energy generation will create problems for the South African government in the near future as center of power in generation will shift from government owned to private owned. The projected effects of privately owned generation will counter or erode government objective of access to affordable electricity, and render the energy economy venerable to multinational manipulation.

In order to promote renewable energy exploration and utilization to the extent required to make it viable on a large scale, government should either invest and support municipalities and select identified small-to-medium enterprises (SMMEs) with the necessary expertise to aid municipalities, and/or institute a public sector institution with similar magnitude and capacity as Eskom that solely focus on green projects and be responsible for the generation and transmission of electricity from renewable energy sources. This will in a manner fast-track remedying the current energy situation and enable the ease of achieving targeted additional energy.

The March 2008 issue of South African Energy Statistics [32] carried a report which stated that the South African economy is dependent on energy resources because almost all economic activities of the country are in one way or the other directly or indirectly linked to energy consumption. The report further reflects that South Africa is a country with less rainfall and abundant sunshine, but still relies on coal as the main source of energy. The report observes that South Africa uses largely fossil based resources, and that guides and regulations have not been fully established to enable supported harnessing of renewable resources on a large enough scale to generate required amount of energy at municipal and subsequently national level.

[33] indicates that the 'source-supply-process' costs of harnessing energy from fossil fuels to secure the country's energy security is a short term solution with severe consequences compared to renewable energy based sources. Thus government must invest in establishing infrastructure that enable and support renewable energy based initiatives.

The 2017 report by Deloitte [34] conveys a synoptic view of electricity consumption and pricing in South Africa and considers the relationship of economic activities of the country to energy demand, and vice versa. The report defines electricity intensity as the amount of electricity consumed to produce a unit of output and states that little transition has been made in shifting from high energy dependent economic activities in the past 30 years and that electricity consumption resulting from such transition or economic activities with relatively less energy-intense result mainly from commercial institutions and government services institution which contribute about $15 \%$ of the total electricity consumption.

[34] further indicated that the energy consumption of water and wastewater treatment plants is dependent on the sensitivity of the technology used at the treatment plants in terms of energy efficiency and the modernization of households as households are responsible for water consumption and sewer load discharge to wastewater treatment plants, as the sewer type dictate the number and type of process activities that must be conducted at the wastewater treatment plants. A study by CSIR [35] indicated that most, if not all municipal wastewater treatment plants in the country use old poorly maintained technology that has no consideration for energy efficiency.

[36] lists the following factors as influencing demand for electricity:

- price of electricity which mainly depends on the type of source used, process of producing electricity and supply status of electricity to demand at hand

- growth in level of economic production

- population growth

- weather patterns, and

- technological advancement

A report presented under the auspices of Project 90 [63] estimates that by 2030 energy transformation in South Africa will result with $69 \%$ of the country's energy production being from coal-based sources, a decrease from the current $92.6 \%$ contribution from the same source. Further [63] indicate that the projected energy produce by 2030 would have a $11 \%$ and $3 \%$ contribution of the total electricity generation from solar and wind sources respectively. Furthermore, the report reflects that biomass energy production will also grow along with solar and wind energy production. The question is: has government established resources and tools to ensure that projected goals are met other than the allocating of funds without any proper detailed plan?

According to the International Energy Agency (IEA) report of 2013 [63] there are two fundamental drivers of demand for electricity at a macroeconomic level; revenue and price. According to the principles of macroeconomics, rising levels of economic activity are normally associated with increased demand for electricity and energy in general, and rising electricity prices tend to reduce energy or electricity consumption. The report states that the other factors that significantly influence the aggregate demand for electricity are energy intensity of economic growth and impact of technological change. The IEA report in essence indicates that the affinity for electricity is greatly influenced by cost associated with electricity generation from type of fuel source used and the type of processing for generation.

Both [63] and [36] indicate that a change in technology has an important impact on electricity demand, though tensions exist between technological factors regarding those that are considered to increase energy demand versus those that decrease energy demand. [63] states that the key drivers or components of electricity demand, based on a decomposition demand approach, are:

- activity effect which is the change in demand due to change in economic activities. The change in economic activities of each sector is known as the gross value-added (GVA). 
- Structural effect which is the change in demand due to change in the mix of economic activities or sectors within the economy, and

- Intensity or efficiency effect which is the change in demand due to change in energy use per unit of sectoral activity.

In support of the above mentioned factors, [38] determines that energy (electricity) demand is influenced by the sector's electricity share effect on total energy demand and the intensity effect. [38] indicates that the share effect is the positive impact of sectors on electricity demand substituting away the dependence on other energy sources towards electricity, whereas the intensity effect is responsible for the dominance in electricity consumption over a period.

Based on the views of [63] and the World Energy Council (WEC) [39] on energy efficiency, [11] states that the reduction in energy consumption associated with technological changes usually focuses on efficiency based electricity intensity, which [40-42] define as the change recorded in electricity intensity in terms of electricity consumption per national production unit in Joules per rand of the GDP. Reduction in energy consumption by this method would result in an improved economic condition that improves electricity consumption of production processes, which is a low cost and effective way of curbing energy demand in the economy [11].

[43] states that the South African industrial electricity efficiency is an ongoing concern as it contributes far less to the South African GDP, and is considerably low than global averages. In order to address this challenge [11] suggests, based on the views of [42], that South Africa's electricity supply shortages require a nation-wide demand-side management programme that will improve energy efficiency.

[44] points out that research institutions are faced with increasing pressure to come up with management technologies that can manage electricity demand and cost reduction caused by energy efficiency. In particular, these technologies are required for many legacy facilities and equipment that were built at a time when energy optimisation was unimportant and the challenges of managing electricity consumption from the national grid were insignificant.

Energy-efficient facilities are not common in South Africa; therefore, technical interventions must be supported in order to achieve energy efficiency [44]. [45] is of the view that wellmotivated personnel are best at developing and implementing energy efficiency policies which can produce benefits such as cost reduction, savings on utility bills, improvements in ways in which facilities and equipment are operated and maintained, and creation of energy efficient systems.

When there is an unbalanced grid, two options exist to restore a stable electricity grid: the first is to increase the supply by building new infrastructure or electricity generating plants, and the second is to decrease energy demand by improving energy efficiency through encouraging consumers to switch off appliances, or switch to renewable energy sources [46]. The author further states that, since it is important to consider time frames, initial capital investment, maintenance and operations costs, as well as potential energy savings, load-shedding is the least popular method to bring about a decrease in demand for electricity, as load-shedding also frightens investor confidence and has negative effects on economic growth activities.

Considering that the government endorsed the building of new coal-fuelled power stations (Medupi and Kusile) which were costly to build and are costly to operate, and taking into account the prices of processing coal to electricity, and, finally, considering the uncertainties of unreliable behavioural of the existing coal-fuelled power stations together with actions by consumers, as stated by [46], this paper aims at suggesting decentralised and diversified generation using renewable energy sources as the future of the energy sector in South Africa that will secure first class economic trade and development with no harmful effects on the environment especially at municipal level.

The energy status of South Africa is at a crisis level because municipal institutions around the country owe Eskom billions of rands leading to heavy national deficits in terms of energy and cash, lack of power capacity, inability of the country to provide reliable energy supply, and reduced ability to drive energy dependent economic activities and service delivery at municipal level. Worsening the situation is that because South Africa cannot claim a reliable energy supply there are threats of a downgrade by rating agencies which affect inward investment and the ability to borrow money, and then there is the issue of corruption which its tremendous impact is difficult to quantify at this stage. This all has a negative impact on South Africa's economic ability and capacity for development [14].

The above analysis is echoed by [47] who states that the critical challenge of addressing power shortages lies with finding money to support renewable energy based initiatives (power supply) and investing in expanding infrastructure that positively supports energy supply and restoration of efficiencies of existing power generating and transmitting infrastructure. [48] echoes concerns expressed by various sources on energy related challenges in South Africa saying that investors are taking their monies and skills elsewhere where their interests will be more safely secured than a country characterised by incapability and incompetence in being able to provide security of energy supply to meet desired operations and rising energy demand projections.

[49] states that government cannot afford to underestimate energy demands as it seems to be doing all the time. Government should invest in comprehensive strategies and capital investments that facilitate and fast-track security of energy supply and counteract the effects (costs) of generating electricity from the fast-depleting coal-based fuels that erode any form of financial savings.

[50] reiterates the challenges of South Africa's electricity supply industry by stating that the power crisis faced by South Africa is as a result of energy generation uncertainty, indicating that the electricity supply industry in South Africa is not open to competition, which is why Eskom (the government's biggest and only trusted energy utility or enterprise) continues to build coal-fired power plants irrespective of being expensive to operate and generate electricity. The author further suggests that the electricity supply industry in South Africa should be opened to competition. 
International Journal of Engineering Research and Technology. ISSN 0974-3154, Volume 13, Number 10 (2020), pp. 2814-2823

(C) International Research Publication House. https://dx.doi.org/10.37624/IJERT/13.10.2020.2814-2823

Although generation did not accommodate full private sector participation in energy generation nor was the private sector allowed to design and influence electricity tariffs in order to give private investors the returns on investment attractive, government is starting to engage private sector institutions through various indaba conferences with the different trade sectors such as mines to achieve far reaching (sustainable) solutions.

[50] writes, diversifying the energy mix with renewable sources addresses long-term energy shortages and WEF recommendations. [50] states that, although additional energy supply from renewable sources is the prime focus, all of the above is fruitless if energy efficiency is not considered, as energy efficiency is one of the major drivers that shapes the environment in which the electricity supply industry is required to deliver electricity now and for decades to come.

[51] states that, although South Africa has a massive target of new energy generation capacity from renewable sources, one of the identified sources for scaling up is the recovery of energy from waste at municipal level.

Based on views expressed by [52], [53] states that the three paramount elements of energy security are sovereignty, robustness and resilience. According to [53], in order for government to speedily achieve adequate energy security, government must work tirelessly, aggressively and have control of processes that address infrastructure backlogs, investment or funding paralysis, inadequate planning and forecasting of resource management, preventions of publicprivate partnership, lack of resource change management, lack of energy efficiency management concept and implementation, and lack of frequent reviews. Further, [53] states that to address the complexity of energy security in South Africa the authors advocate for conceptualisation of energy security that is in line with the World Energy Council's tenets of accessibility, availability and acceptability, also endorsed by the Department of Minerals and Energy.

[54] states that, though small and medium enterprises (SMEs) in South Africa are regarded as the future engines of growth for the South African economy, they are one of the most vulnerable sectors in the face of an unstable energy environment and policy shifts, since SMEs are generally incapable or lack the resources necessary to invest in alternative sources of energy. Because of this vulnerability, the South African economy faces struggling growth within municipal jurisdictions.

Regulations on new generation capacity under the Electricity Regulations Act have been developed to encourage cogeneration which includes current conventional energy sources and renewable sources. The national energy efficiency strategy developed and reviewed in 2017 forms the basis for mandatory biofuel blending regulation [10]. With these policies in place a platform has only been recently created to allow institutions such as municipalities to authentically generate and distribute their own electricity using renewable sources. However, lack of funding or financing of the feasibility of municipalities generating own electricity is lacking. The question is how long will these feasibilities at municipal level be attained during a time when energy solutions are so essential.

\section{RECOMMENDATIONS}

Studies conducted by the United States Environmental Protection Agency in 2013 [55] on energy efficiency in water and wastewater facilities indicated that local municipalities are among the largest consumers of energy in the community, and significant amounts of municipal energy consumption occurs at water and wastewater treatment facilities. The report states that local governments can save energy through employing energy efficiency improvement strategies on both water and wastewater treatment plants within their jurisdiction in order to reduce operating costs, energy consumption and also free resources to embark in additional investments that promote energy conservation. In agreement with the views expressed by the United States Environmental Protection Agency [55], [51] point out that the Constitution of the Republic of South Africa mandates municipalities to responsible for the role of harnessing waste for energy purposes.

Although wastewater treatment plants consume large amounts of energy, the same plants have the capacity to produce large amounts of biogas (a combination of methane and carbon dioxide) from sewage sludge [56]. In support of this [8] states that the process of using harvested natural gas (methane) from natural reserves such as from human waste for the purpose of generating electricity, together with the use of improved appropriate technologies that produce and use the mixture of methane, carbon dioxide and traces of other gases, deserves investment in order to enhance energy generation.

Municipal wastewater treatment plants present untapped sources of renewable energy, and the use of bio-solids can generate biogas that contains up to $70 \%$ methane which can be used to generate electricity [58]. [58] states that over and above having raw sources of energy, municipalities must undertake continuous sub-metering measures of industries and major pieces of equipment in their facilities in order to identify energy-saving opportunities by capturing diurnal variations in electric energy demand so that reviews of equipment replacement or modification and methods of operations can be made.

[59] states that the time has come to challenge the conventional electricity utility business model which is based on a centralised system of generation, transmission and distribution, through the use of disruptive technologies (innovations that when scaled up causes disruption to the basic architecture of the electricity generation system) and 'prosumer' (producerconsumer) electrification. When a disruption occurs in a centralised system the whole grid (nation) gets affected whereas when disruption occurs in a decentralised system, the problem is localised in that area. The benefits among others are reduced repair time, reduced transaction costs and impact to the general economy, and etcetera.

The Mercury newspaper of $4^{\text {th }}$ February 2020 [60] reports that the current Minister of Mineral Resources and Energy at a mining indaba held in Cape Town said that the government was going to focus on two main initiatives: partnering with investors regarding generation of new forms of energy, (with a blueprint setting out the rate and schedule of decommissioning Eskom's ageing coal-fired power plants by 2050), and providing municipalities with autonomy to generate their own 
electricity. The minister claimed that government is currently in the process of gazetting a revised Schedule 2 of the Electricity Regulation Act that will facilitate municipal generation options under 'distributed generation'.

Based on the 2008 Statistician General's report on South Africa's Energy [61] that South Africa has abundant sunshine, partnering with expert investors in solar energy production is a step in the right direction for securing stable and adequate energy supply. Onyekwelu and Akindeke (2006)[62] warn that the most common mistake made by African governments is their tendency of owing allegiance to multinational corporations that are often profit oriented, to the detriment of their citizens.

If each province had their own tailor made renewable energy plants at municipal level, each municipality would have their very own business attraction and model, and each respective province would be an economic hub influenced by the type of and dominant energy generating scheme found in that province. [63] proposes decentralised generation and distribution on the primary grid component with smaller macro-grids being supported by mini-grids.

\section{CONCLUSION}

Based on the above views of the energy supply status in South Africa, the country stands a chance of recovering from its near catastrophic energy crises by finding meaningful strategies that fast-track dealing with the core energy issues in a well-thought out manner. This involves identifying that the energy supply basket must to be opened to diverse forms of energy generation from different sources, that more role players must be introduced in the energy supply sector through partnership agreements with both local (public and private) institutions and multi-national companies, and that energy generation be decentralised to municipalities where mines, industries, and other business activities are located.

\section{ACKNOWLEDGMENTS}

The authors would like to thank the University of KwaZuluNatal for supporting this research under Green Energy Research Group Grant.

\section{REFERENCES}

[1] Oxford South African School Dictionary 2010. 3rd ed. Cape Town: Oxford University Press.

[2] Hinrichs, R.A. and Kleinbach, M. Energy: Its Use and the Environment, 3rd ed. Boston, MA: Cengage, 2002.

[3] Pulfrey, D. Photovoltaic Power Generation. Litton Educational Publishing.Van Nastrand Reinhold Ltd: New York, USA, 1978.

[4] Royston, A. Eco-Action: Energy of the Future. Oxford: Harcourt Education Limited, 2008.

[5] Daw, J., Hallett, K., DeWolfe, J., and Venner, I. Energy
Efficiency Strategies for Municipal Wastewater Treatment Facilities. https://www.nrel.gov/docs/fy 12osti/53341.pdf

[6] Ghosh, B.B. and Nag, A. (2008). Ethanol and Methanol as Fuels in Internal Combustion Engines. In: Nag, A. (ed). Biofuels Refining and Performance. New York: McGraw-Hill, 2008 pp. 191-210.

[7] Richards, J. Future Energy. Paperback Edition. Australia: MacMillan Education Limited, 2008.

[8] Hampton, P.E. Methane and Cogeneration Technology: Renewable Energy Opportunities for Erie County Wastewater Treatment Plants. USA: University of Buffalo, 2007.

[9] Van Zyl, F., Manus, N. and Pensulo, C. Water Services Infrastructure Asset Management for Municipal Managers and Management. Department of Water and Forestry, 2008.

[10] Hasley, R., and Schubert,T. Energy Sector Transformation in South Africa: The status quo of South Africa's energy system. Project 90 by 2030, 2017.

[11] Financial Mail. 2015. South Africa's Energy Crisis, Eskom 2008-2015, Available: http://cdn.bdlive.co.za/ ebooks/Eskom\%20and\%20the\%20SA\%20energy\%20cr isis.pdf

[12] Kohler, M. 2013. Differential Electricity Pricing and Energy Efficiency in South Africa. ERSA working paper 396.

[13] Yelland, C. South Africa:Medupi, Kusile, and the massive cost/time overrun. DM, 7 July 2016.

[14] Barker, F, "Power crisis: a dim outlook: shaken investor confidence will be the biggest drag on SA economic growth," 2008. In: Financial Mail. 2015. South Africa's Energy Crisis, Eskom 2008-2015, Available: http://cdn.bdlive.co.za/ebooks/Eskom\%20and\%20the\% 20SA\%20energy\%20crisis.pdf

[15] Ashbourne, 2019.

[16] Nellenbach, M., Kline, S., Winkler, A. and Varn, J. Understanding America's Water and Wastewater Challenges. Bipartisan Policy center. Charles Mott Foundation, 2017. https://bipartisanpolicy.org/ report/understanding-americas-water-and-wastewaterchallenges/

[17] Eskom. Annual Financial Statements, 2018. www.eskom.co.za , IR2018, Documents , Eskom2018AFS.

[18] President Cyril Ramaphosa. Republic of South Africa (RSA): Acquisition of International Investment Funds. eNews and SABC News: Media Briefing, 2019.

[19] Von Bormann, T. and Gulati, M. The Food Energy Water Nexus: Understanding South Africa's most urgent sustainability challenge. WWF-SA. Cape Town: South Africa, 2014. 
International Journal of Engineering Research and Technology. ISSN 0974-3154, Volume 13, Number 10 (2020), pp. 2814-2823

(C) International Research Publication House. https://dx.doi.org/10.37624/IJERT/13.10.2020.2814-2823

[20] Laspidou, C.S. "ICT and stakeholder participation for improved urban water management in the cities of the future," Water Utility Journal, vol. 8, pp. 79-85, 2014.

[21] Javid, M. "Public and private infrastructure investment and economic growth in Pakistan: an aggregate and disaggregate analysis," Sustainability, vol. 11, pp. 1$22,2019$.

[22] Lanau, M.S. The Growth Return of Infrastructure in Latin America. International Monetary Fund. Washington DC: IMF, 2017.

[23] Creamer Media. Water 2012: A Review of South Africa's Water Sector, 2013.

[24] Carter-Jenkins, S. One Facility's Waste is Another's Energy Source - Three Facilities Earn the Energy Star Combined Heat and Power Award. Washington: EPA, 2008.

[25] Sørensen, B. Renewable Energy. London: Academic Press Inc., 1979.

[26] Nguyen, C., Tang, K., and Won, Y. Reaching Zero-Net Energy at Water and Wastewater Treatment Facilities.Massachusetts: Worcester Polytechnic Institute, 2014.

[27] Modise and Mahota. Department of Energy Report, 2009.

[28] Lam, P.2001. The energy industry in China: Development and Prospects.

https://journals.openedition.org/chinaperspectives/2783

[29] Inglesi-Lotz, R. and Pouris, A.2012. The causality and determinants of energy and electricity demand in South Africa. pp84-89.

https://www.up.ac.za/media/shared/404/ZP_Files/Innov ate\%2009/Articles/the-causality-and-determinants-ofenergy.zp40043.pdf

[30] Lin, Y. and Liu, S.(2010). Grey Systems: Theory and Application. Berlin: Springer-Verlag.

http://www.scielo.org.za/pdf/jesa/v27n1/02.pdf

[31] Ratshomo, K. and Nembahe, R. South African Energy Sector Report. Pretoria: Department of Energy, Energy Policy and Planning, 2018.

[32] South African Energy Statistics.2008.

https://unstats.un.org/unsd/energy/meetings/mexico200 8/Country\%20notes/South\%20Africa.pdf.

[33] Energy White Paper 1998.

[34] Deloitte.2017. Clean Energy Industry Report. Deloitte Research Technology, Media and Telecommunications.

https://www2.deloitte.com/content/dam/Deloitte/cn/Do cuments/technology-media-

telecommunications/deloitte-cn-tmt-clean-techindustry-report-2017-en-180110.pdf

[35] CSIR. The State of Municipal Infrastructure in South
Africa and its Operations and Maintennce; An Overview. 2007.

[36] Platchkov,L.M. and Pollitt, M.G.2011. The Economics of Energy (and Electricity) Demand. EPRG Working Paper 1116 and Cambridge Working Paper in Economics 1137. Electricity Policy Research Group.

https://www.researchgate.net/publication/241753448_T he_Economics_of_Energy_and_Electricity_Demand

[37] International Energy Agency.2013. International Energy Outlook 2013 with Projections to 2040. U.S. Energy Information Administration.

https://www.eia.gov/outlooks/ieo/pdf/0484(2013).pdf

[38] Zhang, M. and Wang, W. (2013). Decoupling analysis of electricity consumption from economic growth in China. Journal of Energy in Southern Africa, Vol 24(2), pp 57-66.

http://www.scielo.org.za/pdf/jesa/v24n2/07.pdf

[39] World Energy Council.2019. World Energy Scenarios: Exploring Innovation Pathways to 2040.

https://www.worldenergy.org/assets/downloads/Scenari os_Report_FINAL_for_website.pdf

[40] Sun, J.W. and Ang,B.W. 2000.Some Properties of an Exact Energy Decomposition Model. Energy, 25, pp1177-1188.

[41] Mukherjee, S. and Chakraborty, D. Turning Human Waste into Renewable Energy: Opportunities and Policy Options for India. Vol. 3, issue 4, pp 610-628, 2016.

https://www.researchgate.net/publication/313800497_T urning_Human_Waste_into_Renewable_Energy_Oppor tunities_and_Policy_Options_for_India

[42] Inglesi-Lotz, R. and Blignaut, J.N.2011. South Afrca's electricity consumption: A sectoral decomposition analysis. Applied Energy, 88, pp4779-4784.

https://www.academia.edu/33239915/Inglesi-

Lotz_and_Blignaut_-_Applied_Energy_2011.pdf

[43] Winkler.H. and Marquard, A.2009. Chanign development paths: From an energy-intensive to lowcarbon economy in South Africa. Climate and development, 1, pp47-65. Energy Research Centre, University of Cape Town.

http://www.erc.uct.ac.za/sites/default/files/image_tool/i mages/119/Papers-2009/09Winkler-

Marquard_Changing_devt_paths.pdf

[44] Maistry, N. and McKay, T.M.2016. Promoting energy efficiency in a South African university. Journal of Energy in Southern Africa, 27(3), pp1-10.

https://www.researchgate.net/publication/309395329_P romoting_energy_efficiency_in_a_South_African_univ ersity

[45] Saini, G. Sustainable Wastewater Treatment through 
Microbial Fuel Cells (MFC). National Workshop on Recent Advancements in Civil Engg, Sharda University, 2017

[46] Xia, X. and Zhang, J. Operation Efficiency Optimisation Modelling and Application of Model Predictive Control. IEEE/CAA Journal of Automatica Sinica, vol. 2, issue 2, pp166-172, 2015.

[47] Smith, N. and Lunsche, S. Financing Eskom's Expansion. Many Rands make light work: Fixing the power shortage will cost R1 trillion by 2025 . Where will the money come from?, 2008. In: Financial Mail. 2015. South Africa's Energy Crisis, Eskom 2008-2015, Available:

http://cdn.bdlive.co.za/ebooks/Eskom\%20and\%20the\% 20SA\%20energy\%20crisis.pdf

[48] Mthombothi, B. Darkness at noon: Eskom, having been refused permission by government to build more power stations, determinedly drove the cart into the ravine, 2008. In: Financial Mail. 2015. South Africa's Energy Crisis, Eskom 2008-2015, Available: http://cdn.bdlive.co.za/ebooks/Eskom\%20and\%20the\% 20SA\%20energy\%20crisis.pdf

[49] Lunsche, S. Can't afford to trip again: The power crisis is forcing Eskom into SA's largest-ever spending plan, 2008. In: Financial Mail. 2015. South Africa's Energy Crisis, Eskom 2008-2015, Available: http://cdn.bdlive.co.za/ebooks/Eskom\%20and\%20the\% 20SA\%20energy\%20crisis.pdf

[50] Joffe, H. "Challenges for South Africa's electricity supply industry," Focus, vol. 64, pp 32-27, 2012. Available: https://hsf.org.za/publications/focus/focus64/Focus64Cweb\%20-2.pdf

[51] Ferry, A., and Giljova, S. Biogas potential in selected wastewater treatment plants. South African Local Government Association and German Cooperation: Deutshe Zusammenarbeit. South Africa, 2015.

[52] Cherp, A. and Jewell, J.2011. The Three Perspectives on Energy Security: Intellectual History, Disciplinary Roots and the Potential for Integration. Current Opinion in Environmental Sustainability, 3,pp1-11.

https://www.researchgate.net/publication/236672467_T he_Three_Perspectives_on_Energy_Security_Intellectu al_History_Disciplinary_Roots_and_the_Potential_for_ Integration

[53] Trollip, H. Butler, A. Burton, J. Caetano, T. and Godinho, C.2014. Energy Security in South Africa:Developing countries exploring pathways to climate compatibility.MAPS, Issue 17.

https://www.africaportal.org/publications/energy- security-in-south-africa/

[54] Ketelhodt, A.V. and Wocke, A.2008. The impact of Electricity on the consumption Behaviour of Small and Medium Enterprises. Journal of Energy in Southern Africa, 19(1), pp4-12.

https://econrsa.org/system/files/publications/working_p apers/working_paper_727.pdf

[55] United States Environmental Protection Agency. Energy Efficiency in Water and Wastewater Facilities. A guide to developing and implementing Greenhouse Gas Reduction Programs. Local Government Climate and Energy strategy guides, 2013. www.epa.gov/statelocalclimate/resources/strategyguides.html.

[56] Pakenas, L.J. Energy Efficiency in Municipal Wastewater Treatment Plants. New York State Energy Research and Development Authority. University of New York, Albany, 1995.

[57] Wong, S.C. Tapping the Energy Potential of Municipal Wastewater Treatment: Anaerobic Digestion and Combined Heat and Power in Massachusetts. Massachusetts Department of Environmental Protection, 2011.

[58] Pirnie, M. Municipal Wastewater Treatment Plant Energy Evaluation for Ithaca Area Wastewater Treatment Facility. New York: Albany, 2005.

[59] Baker, L. and Phillips, J. "Tensions in the transition: the politics of electricity distribution in South Africa." Environment and Planning C: Politics and Space journals, vol. 37, no. 1, pp177-196, 2019..

[60] Faku, D. 2020. Government talking to new energy partners: Looking at options outside of Eskom. Mercury newspaper, $4^{\text {th }}$ February

[61] Lehohla, P. J. 2008. Statistics South Africa Annual Report 2007/2008. Statistician General's report on South Africa's Energy.

[62] Onyekwelu, J.C and Akindele, S.O. Biomass and Bioenergy Research in Tropical Africa: State of the Art Challenges and Future Directions. In: Brenes, D. M. (ed). Biomass and Bioenergy: New Research. Hauppauge, NY: Nova Science Publishers, 2006 pp. 134.

[63] Atkins, P., Hasley, R. and Schubert, T. Renewable Energy Resources: Transforming our Energy Future. Workshop by Project 90 by 2030, 2017. 